\title{
Perbedaan Kedalaman dan Ketebalan Lapisan Termoklin pada Variabilitas ENSO, IOD dan Monsun di Perairan Selatan Jawa
}

\author{
Firman Ramadhan $^{1 *}$, Kunarso ${ }^{1}$, Anindya Wirasatriya ${ }^{1}$, Lilik Maslukah ${ }^{1}$ dan Gentur Handoyo ${ }^{1}$ \\ ${ }^{1}$ Departemen Oseanografi, Jurusan Ilmu Kelautan Fakultas Perikanan dan Ilmu Kelautan Jl. Prof. H. Sudarto, SH \\ Tembalang, Telp/fax (024) 7474698 Semarang 50275 \\ Email: *firmanramadhan10.fr@gmail.com
}

\begin{abstract}
Abstrak
Perairan Selatan Jawa dipengaruhi oleh beberapa fenomena, yaitu sistem monsun, El Niño Southern Oscillation (ENSO) dan Indian Ocean Dipole (IOD), fenomena tersebut mempengaruhi nilai temperatur. Termoklin adalah lapisan yang memiliki gradien temperatur vertikal yang signifikan di kedalaman tertentu, sehingga erat kaitannya dengan nilai temperatur. Penelitian ini dilakukan untuk mengetahui perbedaan kedalaman dan ketebalan lapisan termoklin di wilayah pesisir dan laut lepas pada variabilitas ENSO, IOD dan monsun di perairan Selatan Jawa. Penelitian ini menggunakan data temperatur vertikal harian dari argo float (2016 - 2019) untuk mengetahui distribusi temperatur vertikal. Hasil penelitian menunjukkan bahwa batas atas dan batas bawah termoklin terdalam di pesisir terjadi saat $\operatorname{IOD}(-)$, yaitu tahun 2016 sebesar 60,17 m, 154,58 m dan tahun 2017 sebesar 62,08 m, 154,17 m, sedangkan saat IOD(+) batas atas dan batas bawah termoklin lebih dangkal, yaitu tahun 2018 sebesar 42,92 m, 136,71 m dan tahun 2019 sebesar 39,25 m, 129,63 m. Hasil untuk laut lepas menunjukkan batas atas dan batas bawah termoklin terdangkal di laut lepas terjadi saat IOD(-), yaitu tahun 2016 sebesar 58,92m, 156,25m dan tahun 2017 sebesar $60 \mathrm{~m}, 152,92 \mathrm{~m}$, sedangkan saat IOD (+) batas atas dan batas bawah bertambah dalam, yaitu tahun 2018 sebesar 67,08m, 175,42m dan tahun 2019 sebesar 59m, 172,92m. Hal ini karena IOD(-) di tahun 2016 memiliki nilai indeks DMI sebesar -1 dan di tahun 2019 terjadi IOD(+) dengan nilai indek DMI sebesar 2. Kejadian IOD(-) membuat slope muka air laut di Samudera Hindia bagian Timur khususnya yang lebih dekat dengan pantai menjadi lebih tinggi, sehingga tingginya slope muka air laut membuat batas atas dan batas bawah lapisan termoklin menjadi lebih dalam di pesisir Selatan Jawa Kondisi yang berbeda terjadi di laut lepas dimana slope muka air laut yang lebih rendah daripada di Pesisir menjadikan termoklin lebih dangkal dan ketebalannya lebih tipis., begitu juga sebaliknya pada saat fenomena IOD (+).
\end{abstract}

Kata kunci : Lapisan termoklin, ENSO, IOD, monsun, perairan Selatan Jawa

\begin{abstract}
The waters of South Java are influenced by several phenomena, namely the monsoon system, El Niño Southern Oscillation (ENSO) and Indian Ocean Dipole (IOD), these phenomena greatly affect the temperature value. A Thermocline is defined as a layer that has a significant vertical temperature gradient at a certain depth, so it is closely related to the temperature value. This research was conducted to determine the differences in depth and thickness of the thermocline layer in coastal and open sea areas in terms of the variability of ENSO, IOD and monsoon in the waters of South Java. This study uses daily vertical temperature data from Argo Float (2016 - 2019) to determine the vertical temperature distribution. The results showed that the upper and lower limits of the deepest thermocline on the coast occurred during IOD (-) in 2016-2017 is $60.17 \mathrm{~m}, 154.58 \mathrm{~m}$ and $62.08 \mathrm{~m}, 154.17 \mathrm{~m}$, while during IOD (+) 2018-2019 the upper and lower limits of the thermocline are shallower is $42.92 \mathrm{~m}, 136.71 \mathrm{~m}$ and $39.25 \mathrm{~m}, 129.63 \mathrm{~m}$. The resultsof research for the deep seas show the upper and lower limits of the shallower thermocline on the coast occurred during IOD (-) in 2016-2017 is 156.25m, 97.33m and 152.92m, 92.92m, while during IOD (+) 2018-2019 the upper and lower limits of the thermocline deep increased is $175.42 \mathrm{~m}, 108.33 \mathrm{~m}$ and $172.92 \mathrm{~m}, 113.92 \mathrm{~m}$. This is because IOD (-) in 2016 has a DMI index value of -1 and in 2019 an IOD (+) with a DMI index value of 2. The IOD (-) incident makes the sea level slope in the Eastern Indian Ocean espescially those closer to the beac become higher so that the deep sea level slope makes the upper and lower limits of the thermocline layer deeper in the South coast of Java. Different conditions occur in the deep seas, where the slope of the water level is lower than in the Coast, making the thermocline formed to be shallower and thinner
\end{abstract}

Keywords : Thermocline layer, ENSO, IOD, monsoon, South Java waters 


\section{PENDAHULUAN}

Perairan Selatan Jawa dipengaruhi oleh beberapa fenomena, yaitu sistem monsun, El Niño Southern Oscillation (ENSO) dan Indian Ocean Dipole (IOD) hal ini dikarenakan Indonesia di kelilingi oleh dua samudra yaitu Samudra Pasifik dan Samudra Hindia, fenomena tersebut mempengaruhi nilai arus, kesuburan perairan dan temperatur. Termoklin adalah lapisan yang memiliki gradien temperatur vertikal yang signifikan di kedalaman tertentu, sehingga erat kaitannya dengan nilai temperatur (Aldrian, 2008). Lapisan termoklin berada di antara lapisan mix layer dibagian atas dan deep layer pada bagian bawah, pada bagian mix layer perubahan temperatur terhadap kedalaman masih sangat kecil karena masih ada pengaruh dari atmosfer seperti energi matahari yang masuk kedalam wilayah mix layer, akan tetapi saat memasuki lapisan termoklin yang merupakan kedalaman transisi antara mix layer dan deep layer perubahan temperatur terhadap kedalaman cukup besar yaitu $\geq 0,05^{\circ} \mathrm{C} / \mathrm{m}$ yang merupakan indikasi lapisan termoklin (untuk daerah Samudra Hindia) (Bureau of technical supervision of the P.R of China, 1992 dalam Kunarso et al., 2012), setalah memasuki wilayah deep layer perubahan temperatur terhadap kedalaman mulai mengecil kembali karena sudah tidak ada pengaruh dari atmosfer.

Lapisan termoklin di perairan Indonesia sering dijumpai pada kedalaman 30 - 60 meter dibawah permukaan laut, di Selatan Jawa sampai Timor batas atas termoklin pada kasus El Niño-IOD (-/+) lebih dangkal daripada pada kasus La Niña-IOD(-/+), masing-masing berkisarannya 50,954 -51,704 m dan 58,373-60,180 m. Sedangkan menurut (Song et al., 2007 dalam Kunarso et al., 2012) di Samudra Hindia baru dijumpai lapisan termoklin pada kedalaman 150 - 250 meter, batas atas termoklin kedalamannya berkisar 160-280m, pada kisaran suhu 10-16 ${ }^{\circ}$ C.Ketebalan dan kedalaman lapisan termoklin dikolom perairan dapat berubah, hal ini dikarenakan laut bersifat dinamis. Banyak faktor yang mempengaruhi dari ketebalan maupun kedalaman lapisan termoklin, dipengaruhi oleh arus, upwelling, downwelling, curah hujan, variabilitas iklim (El Niño dan La Niña) dan posisi lintang (Kunarso et al., 2012).

Penelitian ini lebih difokuskan kepada perubahan kedalaman dan ketebalan lapisan termoklin dari pesisir sampai laut lepas kaitannya dengan variabilitas iklim khususnya di perairan Selatan Jawa.

\section{MATERI DAN METODE}

Materi yang digunakan dalam penelitian ini adalah data primer dan data sekunder. Data primer yang digunakan merupakan data temperatur secara vertikal dari tahun 2016 - 2019 yang diperoleh dari Argo float yang dikumpulkan oleh JCOMMOPS (Joint Technical Commission for Oceanography and Marine Meteorology in situ Observations Programme Support Centre) untuk mendapatkan nilai variabilitas temperatur secara vertikal sehingga dapat diketahui keberadaan dari lapisan termoklin. Data sekunder yang digunakan adalah data ENSO menggunakan ONI (Oceanic Niño Index) yang merupakan data anomali SPL di wilayah Niño3.4, yaitu Samudra Pasifik Barat dan Samudra Pasifik Timur, data IOD menggunakan DMI (Dipole Mode Index) yang merupakan data anomaly SPL di wilayah Samudra Hindia Barat dan Samudra Hindia Timur, dan data sebaran temperatur secara horizontal dari tahun 2016 - 2019 yang diperoleh dari satelit Marine Copernicus Global Reanalysis PHY untuk mendapatkan nilai temperatur secara horizontal yang digunakan untuk melihat nilai SPL dari tiap musim di perairan Selatan Jawa.

Metode penelitian yang digunakan dalam penelitian ini adalah metode penelitian kuantitatif. Lokasi penelitian berada di perairan Selatan Jawa yang berada pada koordinat geografis sebagai berikut $6^{\circ} \mathrm{LS}$ $15^{\circ} \mathrm{LS}$ dan $105^{\circ} \mathrm{BT}-115^{\circ} \mathrm{BT}$ (Gambar 1). 


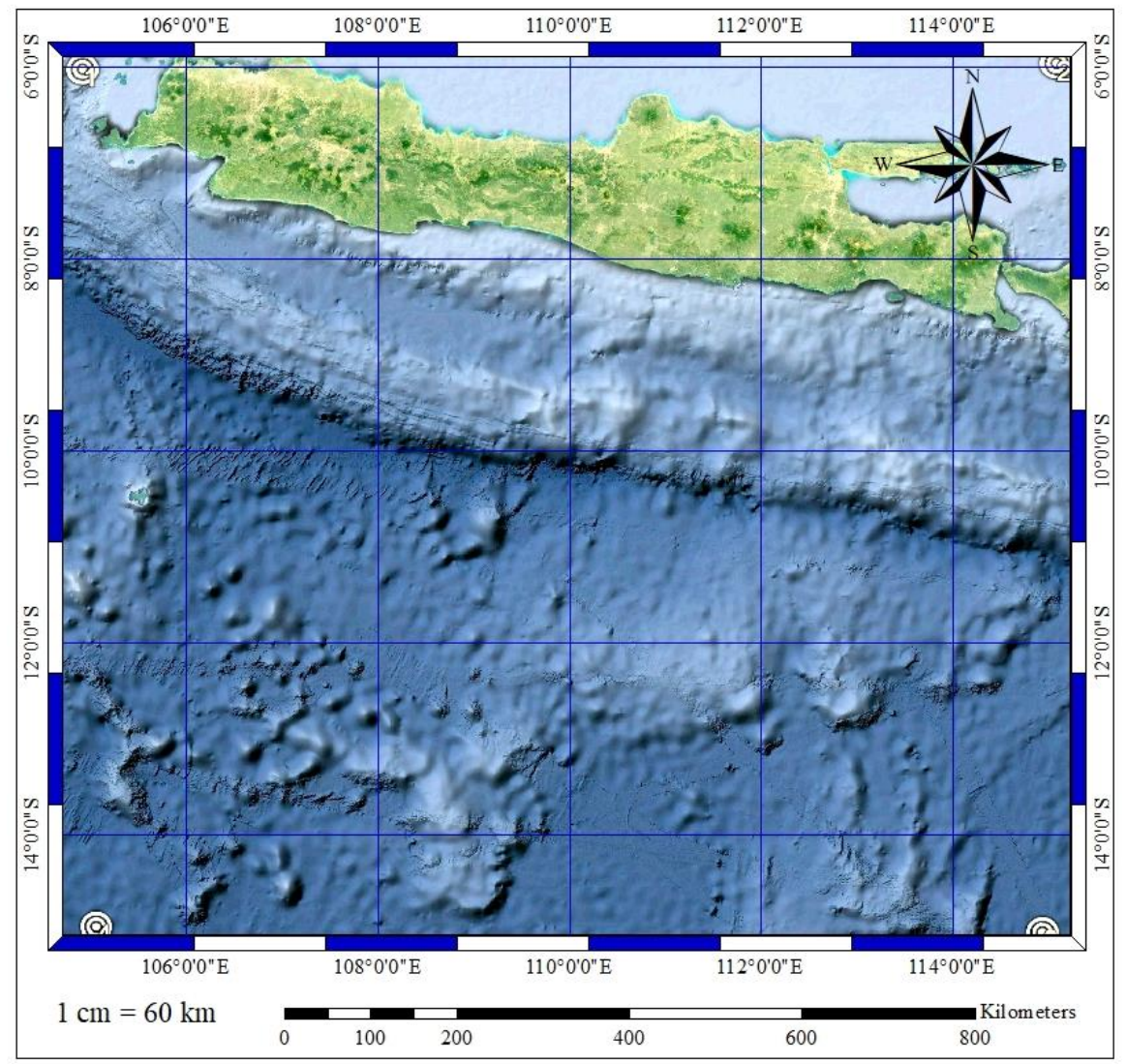

Gambar 1. Peta Lokasi Penelitian

\section{Metode Pengumpulan Data}

Data temperatur secara vertikal dalam penelitian ini diperoleh dari data argo float dari tahun 2016 2019 di perairan Selatan Jawa dengan resolusi vertikal sebesar 151 level to $2000 \mathrm{~m}$, yang merupakan data harian (daily) dari organisasi JCOMMOPS (Joint Technical Commission for Oceanography and Marine Meteorology in situ Observations Programme Support Centre) yang dapat di akses secara bebas melalui http://argo.jcommops.org. Data temperatur secara horizontal dalam penelitian ini diperoleh dari data citra satelit Marine Copernicus dari tahun 2016 - 2019 di perairan Selatan Jawa dengan resolusi spasial 0.083 degree x 0.083 degree yang merupakan data bulanan (monthly) dan dapat di akses secara bebas melalui http://marine.copernicus.eu/. Data variabilitas iklim ENSO menggunakan data Oceanic Niño Index (ONI) selama 4 tahun (2016 - 2019) yang merupakan nilai anomali SPL di wilayah Niño3.4, yaitu Samudra Pasifik Barat dan Samudra Pasifik Timur, format dari data ini adalah tab delimited yang dapat diakses secara bebas melalui https://origin.cpc.ncep.noaa.gov/. Data variabilitas iklim IOD menggunakan data Dipole Mode Index (DMI) selama 4 tahun (2016 - 2019) yang merupakan nilai anomali SPL di wilayah Samudra Hindia Barat dan Samudra Hindia Timur, format dari data ini adalah NetCDF (Network Common Data Format) dengan extension .nc yang dapat diakses secara bebas melalui https://stateoftheocean.osmc.noaa.gov/.

\section{Metode Pengolahan Data}

Data harian temperatur secara vertikal argo float dari tahun 2016 - 2019 dengan extension .nc di input kedalam ODV untuk diekspor kedalam bentuk tab delimeted, data tersebut dibuka menggunakan MS Excel yang kemudian dicari nilai gradien temperatur secara vertikal dan kedalaman termoklin. Adapun rumus gradien temperatur (Song et al., 2007 dalam Kunarso et al., 2012), yaitu : 
Keterangan:

$$
G j=\frac{T_{j+1}-T j}{D_{j+1}-D j}
$$

$\mathrm{Gj} \quad$ : Nilai perubahan temperatur secara vertikal terhadap kedalaman

$\mathrm{Tj} \quad$ : Temperatur perairan pada kedalaman $\mathrm{Dj}$

$\mathrm{Dj} \quad$ : Kedalaman perairan pada kedalaman $\mathrm{Dj}$

Perhitungan kedalaman termoklin dengan formula yang digunakan oleh Kunarso et al. (2012), sebagai berikut :

$$
\mathrm{H}=\{\Delta \mathrm{T} /(\max \partial \mathrm{T}(\mathrm{z}) / \partial \mathrm{z})\}
$$

Keterangan:

$\mathrm{H}$

$\Delta \mathrm{T}$

$(\max \partial \mathrm{T}(\mathrm{z}) / \partial \mathrm{z})$
: Kedalaman Termoklin

: Gradien Temperatur

: Perubahan temperature terhadap kedalaman

Data tersebut kemudian disimpan dengan menggunakan format tab delimited dan diolah kembali menggunakan ODV untuk selanjutnya di proses menjadi data time series menggunakan fitur windows section untuk menganalisa lapisan termoklin yang dikaitkan dengan ENSO, IOD dan Monsun.

Data bulanan citra satelit Marine Copernicus dari tahun 2016 - 2019 dengan extension nc di input kedalam ODV untuk kemudian di ekspor kedalam bentuk tab delimited. Data dalam bentuk tab delimited dibuka menggunakan Microsoft Excel kemudian data bulanan tersebut di komposit menjadi data bulanan klimatologi dari tahun 2016 - 2019 menggunakan rumus komposit bulanan klimatologi (Wirasatriya et al., 2017), yaitu :

$$
\overline{\mathrm{X}}_{k}(x, y)=\frac{1}{n} \sum_{i=1}^{n} X i(x, y, t)
$$

Keterangan :

$\overline{\mathrm{X}}_{k}(x, y) \quad$ : rata - rata bulanan klimatologi

$X i(x, y, t) \quad$ : data bulanan ke-i komposit pada posisi bujur $(\mathrm{x})$, lintang $(\mathrm{y})$ dan waktu $(\mathrm{t})$

$\mathrm{n} \quad:$ jumlah total bulanan komposit (8 tahun)

$\mathrm{i}=1 \quad$ : periode pengamatan ke-i pada bulan komposit

Data tersebut kemudian disimpan dengan menggunakan format tab delimited dan diolah kembali menggunakan ODV untuk selanjutnya di proses menjadi data time series menggunakan fitur windows surface untuk menganalisa variabilitas SPL secara horizontal yang dikaitkan dengan ENSO dan IOD.

Data ONI (Oceanic Niño Index) untuk mengidentifikasi ENSO memiliki format data tab delimited, diolah menggunakan bahasa pemprograman menggunakan algoritma dengan klasifikasi berdasarkan (Hutabarat et al., 2018) sebagai berikut :

$$
\begin{gathered}
\left.-0.5^{\circ} \mathrm{C}<\mathrm{ONI}<+0.5^{\circ} \mathrm{C} \text { (normal }\right) \\
\mathrm{ONI}>+0.5^{\circ} \mathrm{C}(\text { El Niño }) \\
\mathrm{ONI}<-0.5^{\circ} \mathrm{C}(\text { La Niña })
\end{gathered}
$$

Data DMI (Dipole Mode Index) untuk mengidentifikasi IOD memiliki format data dengan extension .nc, diolah menggunakan bahasa pemprograman menggunakan algoritma dengan klasifikasi berdasarkan (Hope et al., 2015), sebagai berikut : 


$$
\begin{gathered}
-0.4^{\circ} \mathrm{C}<\mathrm{DMI}<+0.4^{\circ} \mathrm{C} \text { (normal) } \\
\mathrm{DMI}>+0.4^{\circ} \mathrm{C}(\mathrm{IOD}+) \\
\mathrm{DMI}<-0.4^{\circ} \mathrm{C}(\mathrm{IOD}-)
\end{gathered}
$$

Kedua data tersebut dikomposit menggunakan bahasa pemprograman sehingga menjadi satu grafik yang menampilkan data ENSO dan IOD secara time series.

\section{HASIL DAN PEMBAHASAN}

\section{Variabilitas Iklim ENSO, IOD dan Monsun terhadap SPL di Perairan Selatan Jawa}

Fenomena IOD dan fenomena ENSO di perairan Selatan Jawa (Gambar 2), ketika nilai DMI positif akan mempengaruhi nilai SPL di perairan Selatan Jawa menjadi lebih dingin, sebaliknya ketika DMI negatif dapat mempengaruhi SPL di perairan Selatan Jawa menjadi lebih hangat. Hal yang sama terjadi pada saat fenomena ENSO, ketika nilai ONI positif akan membuat nilai SPL di perairan Selatan Jawa lebih dingin dan ketika nilai ONI negatif dapat berdampak SPL di perairan Selatan Jawa lebih hangat. Hal ini dapat terjadi karena pada saat nilai DMI positif nilai anomali SPL di Samudera Hindia Timur lebih kecil dibandingkan nilai anomali SPL di Samudera Hindia Barat, sehingga SPL di perairan Selatan Jawa menjadi lebih dingin, begitu juga sebaliknya pada saat nilai DMI negatif nilai anomali SPL di Samudera Hindia Timur lebih besar dibandingkan nilai anomali SPL di Samudera Hindia Barat, sehingga SPL di perairan Selatan Jawa menjadi lebih hangat. Hal yang serupa terjadi pada fenomena ENSO di Samudera Pasifik ketika nilai ONI positif, anomali SPL di Samudera Pasifik Barat lebih kecil dibandingkan anomali SPL di Samudera Pasifik Timur, begitu juga sebaliknya ketika nilai ONI negatif, anomali SPL di Samudera Pasifik Barat lebih besar dibandingkan anomali SPL di Samudera Pasifik Timur, massa air di Samudera Pasifik Barat akan dibawa oleh arus ARLINDO menuju perairan Selatan Jawa melalui Selat Bali dan Selat Lombok. Menurut (Kunarso et al., 2012) pembentukan pusat tekanan udara (rendah/tinggi) di Samudera Hindia sangat di pengaruhi oleh variabilitas iklim ENSO (El Niño/ La Niña) dan IOD (DMI+/DMI-), hal ini memiliki pengaruh yang besar terhadap pembentukan variabilitas angin monsun di wilayah Indonesia.

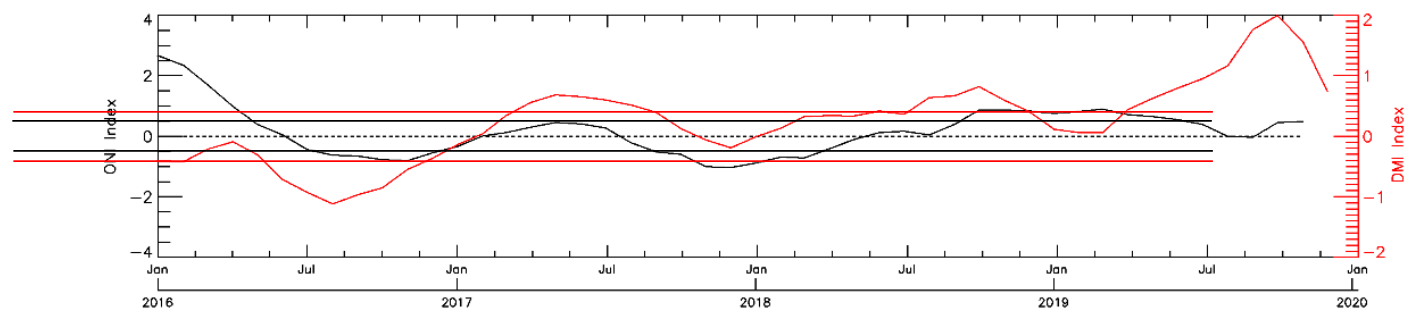

Gambar 2. Grafik timeseries vairabilitas iklim (ENSO (indeks ONI)) dan (IOD (indeks ONI)) selama 4 tahun (2016-2019).

Kejadian IOD (+) menyebabkan pusat tekanan udara tinggi terjadi di Samudera Hindia bagian Timur sehingga angin timuran di perairan Selatan Jawa juga semakin menguat dan membuat upwelling di wilayah tersebut semakin besar. Monsun timur merupakan salah satu pembangkit dari upwelling secara tahunan yang terjadi berkisar bulan Juni - Oktober, hal ini berdampak kepada nilai SST yang semakin rendah di perairan Selatan Jawa. Sebaliknya, kejadian IOD (-) menyebabkan pusat tekanan udara rendah terjadi di Samudera Hindia bagian Timur sehingga angin timuran di perairan Selatan Jawa juga semakin lemah dan membuat upwelling di wilayah tersebut semakin kecil.

\section{Variasi Musiman SPL di Perairan Selatan Jawa}

Suhu Permukaan Laut di perairan Selatan Jawa sangat dipengaruhi oleh sistem monsun, hal ini dapat ditunjukan pada (Gambar 3), puncak SPL tertinggi terjadi pada musim peralihan 1 sebaliknya SPL terendah terjadi pada musim timur. Hal ini dikarenakan perairan Indonesia sangat dipengaruhi oleh sistem monsun. 
Sistem monsun memiliki keterkaitan dengan pergerakan dan kekuatan angin, saat musim peralihan 1 SPL tinggi, hal ini terjadi karena adanya proses konveksi angin yang rendah. Musim timur SPL rendah, hal ini terjadi karena adanya proses konveksi angin yang tinggi dari timur sehingga terjadi upwelling yang kuat di perairan Selatan Jawa. Awal munculnya upwelling umumnya di mulai dari perairan selatan Pulau Sumba dan selatan Bali hingga Jawa Timur, kemudian meluas ketimur hingga selatan Pulau Flores dan ke barat hingga barat Sumatra. Selain upwelling, konveksi angin juga dapat memicu terbentuknya transport Ekman, evaporasi dan pencampuran massa air secara vertikal (mixing) juga dapat mempengaruhi pendinginan SPL di perairan Selatan Jawa.

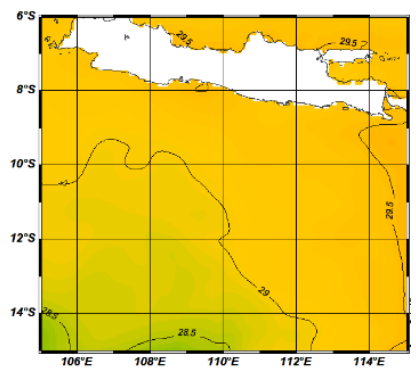

Januari

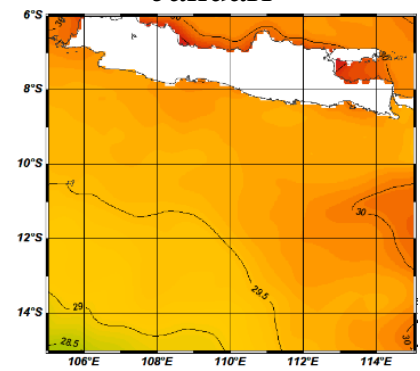

April

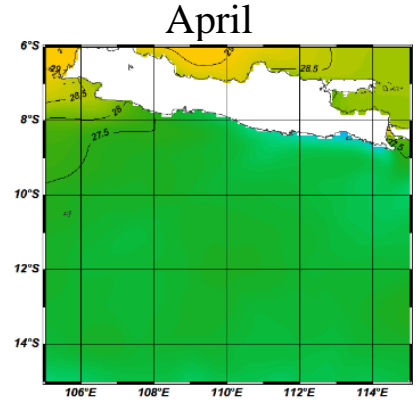

Juli

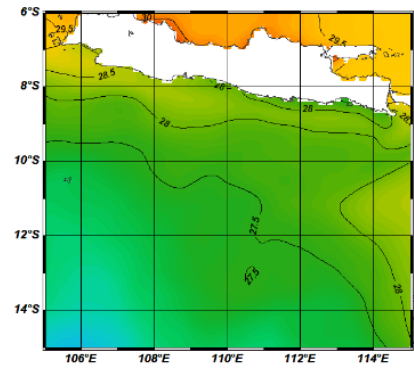

Oktober

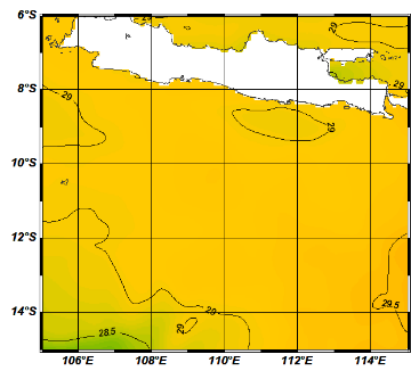

Februari

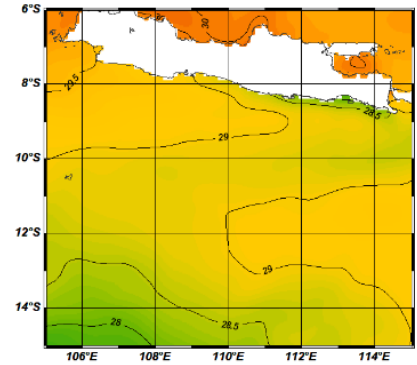

Mei

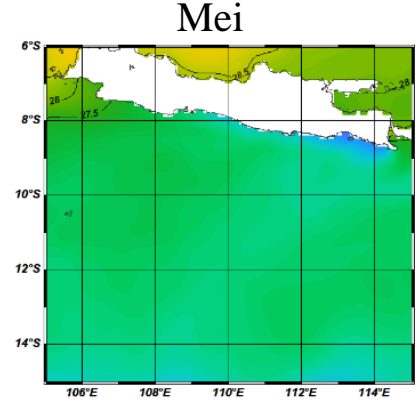

Agustus

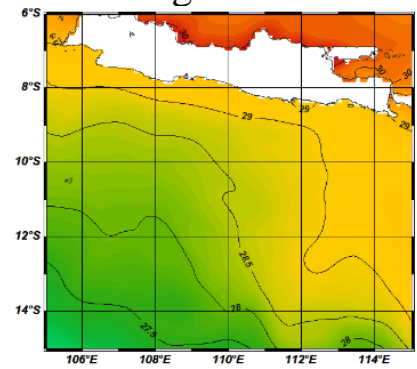

November

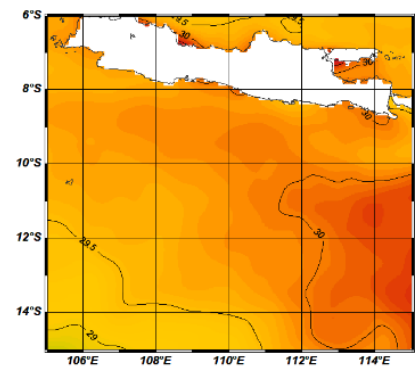

Maret

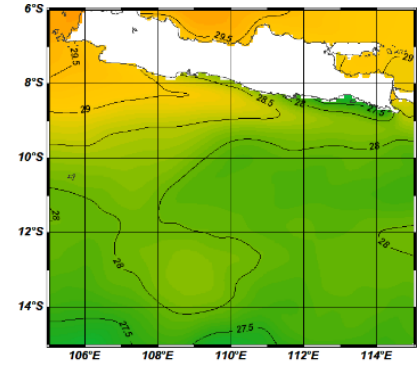

Juni

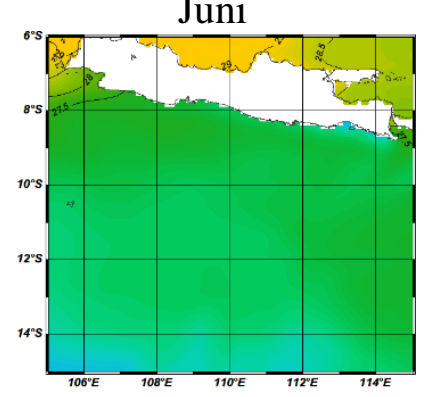

September

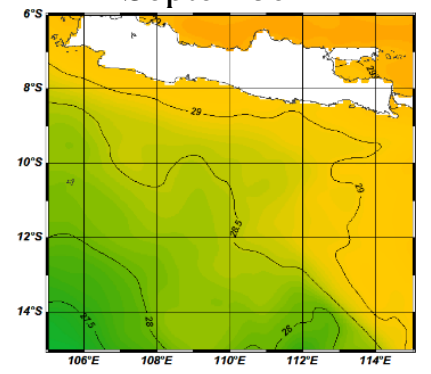

Desember

Gambar 3. Variasi musiman SPL di Selatan Jawa Selama 4 tahun (2016 -2019) 
Selain monsun, ada parameter lain yang dapat menunjang nilai SPL di perairan Selatan Jawa khususnya pada saat pendinginan, yaitu gelombang Kelvin. Hal ini didukung oleh penelitian (Delman et al., 2016) bahwa gelombang Kelvin merupakan penunjang dalam pendinginan anomali SPL di perairan Selatan Jawa dan memiliki dampak langsung terutama pada tahun IOD (+). Mekanisme terjadinya gelombang Kelvin di perairan Selatan Jawa pada awalnya gelombang tersebut datang dari Samudera Hindia menuju perairan Barat Sumatra, di perairan tersebut terdapat South Java Current (SJT) sehingga massa air yang dibawa gelombang Kelvin diteruskan oleh SJT menuju perairan Selatan Jawa. Pendinginan anomali SPL di perairan Selatan Jawa ini terbagi kedalam dua fase, yaitu fase initiation (pada bulan Mei-Juli) dan fase persistensi (pada bulan Agustus-September). Hal ini pun linier dengan hasil SPL klimatologi yang sudah diolah, Ketika bulan Mei-Juli (musim peralihan1-musim timur) SPL di perairan Selatan Jawa mengalami penurunan dan memasuki bulan Agustus-September perairan Selatan Jawa mengalami puncak pendinginan, pada bulan Juni-Agustus di wilayah Australia sedang memasuki musim dingin dan anomali SST dingin dapat meluas hingga ke seluruh wilayah Samudra Hindia bagian timur pada bulan Agustus-Oktober.

\section{Perbandingan Variabilitas Temperatur, Gradien Temperatur dan Lapisan Termoklin di Pesisir dan Laut Lepas Selatan Jawa}

Ketebalan dan kedalaman lapisan termoklin di pesisir Selatan Jawa (Gambar 4) menunjukkan bahwa nilai rerata batas atas dan batas bawah terdalam lapisan termoklin berada pada tahun 2016 - 2017 secara berurutan adalah $60,17 \mathrm{~m}, 154,58 \mathrm{~m}$ dan $62,08 \mathrm{~m}, 154,17 \mathrm{~m}$, hal ini terjadi karena fenomena IOD(-) yang cukup signifikan di tahun 2016 dengan nilai indeks DMI sebesar -1. Fenomena tersebut membuat pesisir Selatan Jawa lebih hangat, sehingga massa air hangat menekan lapisan termoklin menuju kedalaman yang lebih dalam. Kejadian fenomena IOD(-) membuat slope muka air laut di Samudera Hindia bagian Timur menjadi lebih tinggi daripada bagian barat, sehingga tinggi-nya slope muka air laut membuat kedalaman batas atas lapisan termoklin menjadi lebih dalam khususnya didaerah upwelling, hal ini dikarenakan proses upwelling di perairan tersebut menjadi berkurang diakibatkan karena naik-nya slope muka air laut. Nilai rerata batas atas dan batas bawah terdangkal terjadi pada tahun 2018 - 2019 secara berurutan adalah 42,92 $\mathrm{m}, 136,71 \mathrm{~m}$ dan $39,25 \mathrm{~m}, 129,63 \mathrm{~m}$, hal ini dikarenakan fenomena IOD(+) di tahun tersebut cukup tinggi dengan nilai indeks DMI sebesar 2. Kejadian tersebut membuat massa air di pesisir Selatan Jawa lebih dingin dari biasanya, sehingga dapat mengangkat lapisan termoklin menuju perairan yang lebih dangkal. Kejadian fenomena IOD(+) membuat slope muka air laut di Samudera Hindia bagian Timur menjadi lebih rendah daripada bagian barat, rendahnya slope muka air laut membuat kedalaman termoklin menjadi lebih dangkal khususnya didaerah upwelling.

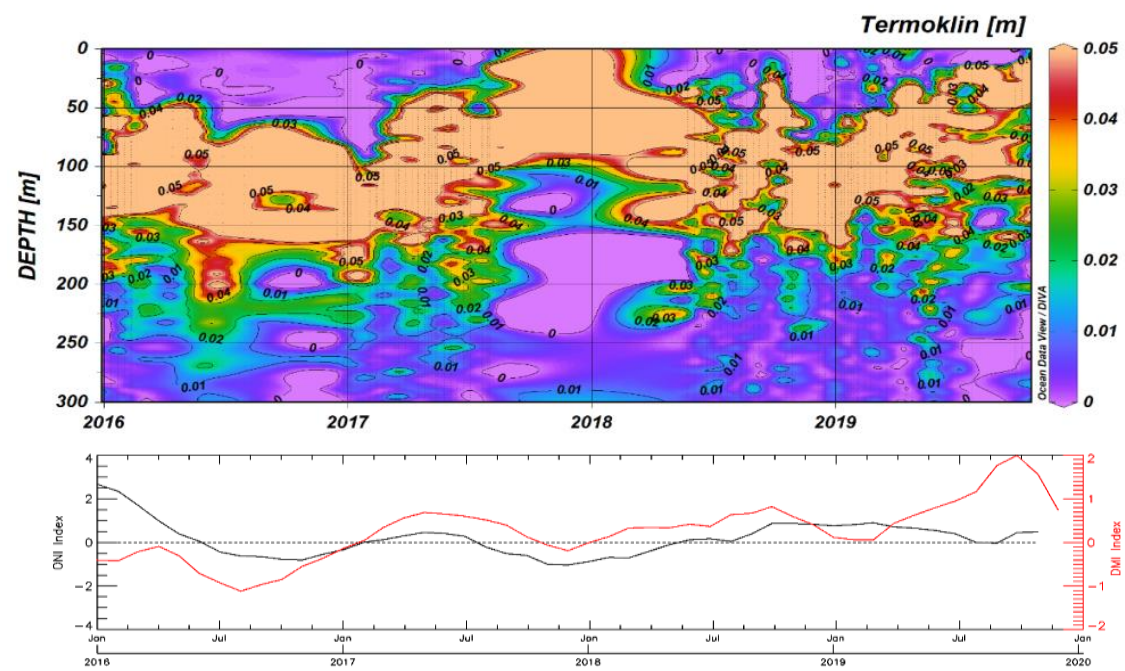

Gambar 4. Variabilitas lapisan termoklin di pesisir Selatan Jawa (2016-2019). 
Ketebalan dan kedalaman lapisan termoklin musiman di laut lepas Selatan Jawa (Gambar 5) nilai rerata batas bawah dan ketebalan lapisan termoklin di tahun 2016-2017 menjadi lebih dangkal, yaitu 156,25 m, 97,33 m dan 152,92 m, 92,92 m, sedangkan pada tahun 2018-2019 nilai rerata batas bawah dan ketebalan lapisan termoklin sebesar 175,42 m, 108,33 m dan 172,92 m, 113,92 m. Kejadian tersebut diduga disebabkan tahun 2016 terjadi fenomena IOD(-) yang cukup signifikan dengan nilai indeks DMI sebesar - 1 dan di tahun 2019 terjadi fenomena IOD(+) yang cukup tinggi dengan nilai indek DMI sebesar 2. Kejadian tersebut terjadi karena wilayah laut lepas terjadi upwelling yang lebih rendah dari pada di wilayah pesisir, sehingga pada saat fenomena IOD(-) slope muka air laut menjadi lebih tinggi dan membuat batas bawah bergerak menuju kedalaman yang lebih dangkal. Sebaliknya pada saat fenomena $\operatorname{IOD}(+)$ slope muka air laut menjadi lebih rendah dan membuat batas bawah bergerak menuju kedalaman yang lebih dalam. Batas atas untuk di laut lepas tidak terlalu terpengaruh, hal ini dikarenakan di wilayah laut lepas memiliki perubahan temperatur terhadap kedalaman cukup kecil untuk di wilayah mix layer sehingga kenaikan slope muka air laut tidak terlalu mempengaruhi batas atas dari lapisan termoklin dan ketebalan lapisan termoklin akan lebih besar saat terjadi fenomena $\operatorname{IOD}(+)$.

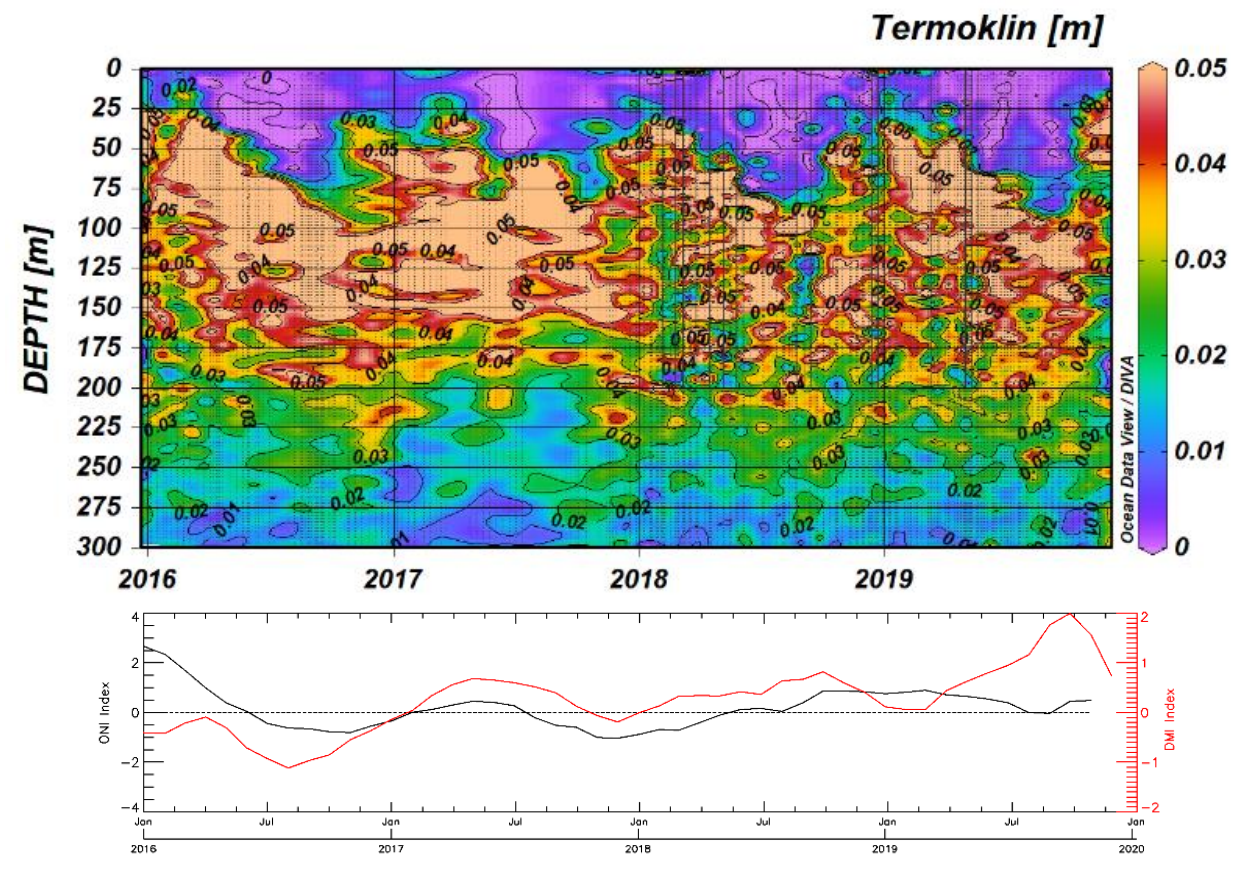

Gambar 5. Variabilitas lapisan termoklin di Laut Lepas Selatan Jawa (2016-2019).

Keterkaitan lapisan termoklin dengan sistem monsun, bahwa pada saat musim barat - peralihan 1 , parairan di Selatan Jawa cenderung lebih hangat dibanding pada saat musim timur - peralihan 2 (Gambar 45). Ketika pendinginan karena sistem monsun dan fenomena ENSO maupun fenomena IOD sedang linier (musim timur - peralihan 2, El Niño, IOD(+)) diduga proses upwelling akan lebih kuat sehingga suhu perairan Selatan Jawa lebih dingin dari biasanya dan lapisan termoklin terangkat oleh proses upwelling sehingga lebih dangkal. Fenomena ini tidak akan terjadi ketika ketiga faktor tersebut saling bertolak belakang, begitu juga sebaliknya. Hal ini pun diperkuat dengan penelitian (Nofiyanti et al., 2017) yang menyatakan bahwa kedalaman zona percampuran dan termoklin di perairan Selatan Jawa berubah mengikuti pola monsun.

Adapun hal lain yang memperkuat sistem pendinginan di wilayah perairan Selatan Jawa khususnya pesisir adalah karena adanya gelombang Kelvin, gelombang Kelvin dipesisir dapat mempengaruhi arus bawah permukaan dan struktur suhu perairan Selatan Jawa, dapat meninggikan atau menekan termoklin sebesar \pm 50 meter dari kedalaman rata-rata. Gelombang Kelvin dapat memperdalam lapisan termoklin ketika nilai Kelvin memiliki anomali positif dan ketika nilai Kelvin anomali negatif dapat menyangga lapisan termoklin menuju kedalaman yang lebih dangkal (Delman et al., 2016). 
Daerah perairan Selatan Jawa khususnya bagian pesisir memiliki hal lain yang menyebabkan sistem pendinginan yang kuat, yaitu proses upwelling. Monsun Tenggara pada bulan Juni sampai September menyebabkan angin monsun tenggara berhembus di sepanjang garis pantai dan sekitarnya, hal ini menyebabkan terjadinya transportasi Ekman ke arah Barat Daya dan Selatan, arus ini mengakibatkan kekosongan massa air di perairan pesisir Selatan Jawa yang memicu terjadinya upwelling sehingga massa air hangat yang berada di permukaan tergantikan dengan massa air yang lebih dingin. Proses di atas sesuai yang dijelaskan oleh (Horii et al.,2018). Hasil penelitian (Flora et al., 2015) juga membahas sistem pendinginan di pesisir Selatan Jawa khususnya bagian timur. Hasil penelitian tersebut menyebutkan bahwa pesisir Selatan Jawa bagian Timur $\left(8.5^{\circ}-11^{\circ} \mathrm{LS}\right)$ terdapat arus Eddy yang memiliki pola sirkulasi di kedalaman $100 \mathrm{~m}$, pada kedalaman $150 \mathrm{~m}$ pusaran arus mulai melemah dan sudah mulai hilang pada kedalaman $200 \mathrm{~m}$. Arus ini bergerak searah jarum jam dan menyebabkan upwelling di perairan tersebut, sehingga mengangkat lapisan termoklin ke perairan yang lebih dangkal dan SPL di wilayah tersebut menjadi lebih dingin.

\section{KESIMPULAN}

Variabilitas iklim global tampak mempengaruhi batas atas, batas bawah dan kedalaman lapisan termoklin khususnya di daerah pesisir Selatan Jawa, sedangkan di wilayah laut lepas Selatan Jawa variabilitas iklim global tidak terlalu mempengaruhi batas atas dan kedalaman lapisan termoklin. Ketebalan lapisan termoklin di wilayah pesisir Selatan Jawa tampak tidak terlalu jauh berbeda nilainya, namun untuk wilayah laut lepas Selatan Jawa sangat terlihat perbedaan ketebalan dan batas bawah lapisan termoklin. Fenomena IOD(-) membuat slope muka air laut di Samudera Hindia bagian Timur menjadi lebih tinggi daripada bagian barat, sehingga tinggi nya slope muka air laut membuat kedalaman batas atas lapisan termoklin menjadi lebih dalam khususnya didaerah upwelling, sedangkan kejadian fenomena $\operatorname{IOD}(+)$ membuat slope muka air laut di Samudera Hindia bagian Timur menjadi lebih rendah daripada bagian barat, rendah-nya slope muka air laut membuat kedalaman termoklin menjadi lebih dangkal khususnya didaerah upwelling.

\section{DAFTAR PUSTAKA}

Aldrian, E. (2008). Meteorologi Laut Indonesia. Jakarta: Badan Meteorologi dan Geofisika.

Delman, A. S., J. Sprintall, J. L. McClean, and L. D. Telley. (2016). Anomalous Java Cooling at the Initiation of Positive Indian Ocean Dipole Events. Journal of Geophysical Research: Oceans, 121, 5805-5824. https://doi.org/10.1002/2016JC011635.Received

Flora, S. M., H. Setiyono, dan A. R. Tisiana. (2015). Pengaruh lapisan termoklin terhadap kandungan oksigen terlarut di Samudera Hindia bagian timur. Jurnal Oseanografi, 4, 185-194.

Hope, P., P. Reid, S. Tobin, M. Tully, and P. Krummel. (2015). Seasonal climate summary southern hemisphere ( spring 2014 ): El Niño continues to try to break through, and Australia has its warmest spring on record. Australian Meteorological and Oceanographic Journal, 65(2), 267-292. https://doi.org/10.22499/2.6502.006

Horii, T., I. Ueki, and K. Ando. (2018). Coastal Upwelling Events Along the Southern Coast of Java During the 2008 Positive Indian Ocean Dipole. Journal of Oceanography, 74: 499-508. https://doi.org/10.1007/s10872-018-0475-z

Hutabarat, M. F., N. P. Purba, S. Astuty, M. L. Syamsuddin, dan A. R. T. D. Kuswardani. (2018). Variabilitas lapisan termoklin terhadap kenaikan mixed layer depth (MLD) di Selat Makassar. Jurnal Perikanan Dan Kelautan, 9(1), 9-21.

Kunarso, S. Hadi, N. S. Ningsih, dan M. S. Baskoro. (2012). Perubahan kedalaman dan ketebalan termoklin pada variasi kejadian ENSO , IOD dan Monsun di Perairan Selatan Jawa hingga Pulau Timor. Ilmu Kelautan, 17(2), 87-98.

Nofiyanti, K., Kunarso, dan A. R. T. D. Kuswardani. (2017). Kajian kedalaman mixed layer dan termoklin kaitannya dengan monsun di perairan selatan pulau Jawa. Jurnal Oseanografi, 6(1), 131-143.

Wirasatriya, A., R. Y. Setiawan, and P. Subardjo. (2017). The Effect of ENSO on the Variability of 
Chlorophyll-a and Sea Surface Temperature in the Maluku Sea. IEEE Journal of Selected Topics in Applied Earth Observations and Remote Sensing, 10(12), 1-6. 